J.S. van der Walt

Navorsingsgenoot, Departement Ou- en

Nuwe Testamentiese

Studies, Universiteit

van die Vrystaat,

Bloemfontein,

Suid-Afrika.

E-pos:

ideo@caw.org.za

DOI: http://dx.doi.

org/10.18820/23099089/

actat.Sup26.2

ISSN 1015-8758 (Print) ISSN 2309-9089 (Online)

Acta Theologica 2018

Suppl 26:38-56

(C) Creative Commons

With Attribution (CC-BY)
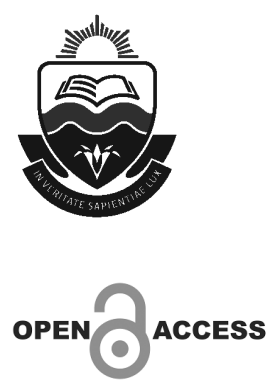

\section{WATER AS MOTIEF IN EKSODUS 14-15; \\ 2 KONINGS 2 EN \\ MATTEUS 14:22-33: 'N \\ VERGELYKENDE STUDIE}

\section{ABSTRACT}

WATER AS MOTIF IN EXODUS 14-15; 2 KINGS 2 AND MATTHEW 14:22-33: A COMPARITIVE STUDY

In the Canon of Scriptures, three decisive turning points (epochs) mark their course with the intensification of miracles. These miracles are craftily described in micronarratives that are, in turn, imbedded within macronarratives. Many of the written miracle stories in the three main macro-narratives (or rather, epochs) have noticeable resemblances when compared to each other. Narratological features such as structure, settings, themes and motifs have striking similarities. In some instances, it appears that one story was built upon another. If this is the case, the question arises as to how far the story can go. This paper will ponder over this question by comparing one miracle story in each of the three main epochs, respectively. The main focus will be on the narrative motif of water found in Exodus 15, 2 Kings 2, and Mathew 14:22-33.

\section{INLEIDING}

Hierdie artikel word aan prof. Fanie Snyman, my studie promotor tydens die skryf van my PhDtesis, A biblical-theological investigation of the phenomenon of wonders surrounding Moses, Elijah and Jesus, opgedra. In een van sy artikels noem prof. Snyman (2000:91) dat daar, in die lees van die mikro-verhale binne die groter makro-verhale van die 
Ou Testament, vir die postmoderne leser van die Bybel nuwe, opwindende moontlikhede bestaan om die boodskap van die Bybel te verstaan. Dit is juis in die lees van die mikro-verhale dat die tema van wonders vir Van der Walt (2014) verras het, veral gegewe die feit dat hierdie wonderverhale in drie spesifiek afgebakende tydsgleuwe (epogs) te bespeur is (Sabourin 1971:240). Die drie epogs sluit in die verhale wat opgeteken is in Eksodus 1-18, 1 Konings 17 tot 2 Konings 2 in die Ou Testament en die Sinoptiese Evangelies in die Nuwe Testament. Interessant genoeg, verskyn die drie hooffigure van hierdie drie tydperke op een oogopslag saam in die verhaal van die verheerliking op die berg (Mark 9:1-8). Bybelkenners is dit eens dat Moses, Elia en Jesus nie alleen prominente figure in die drie verskillende epogs is nie, maar dat hulle ook spesifieke kenmerke van elk van hierdie epogs verteenwoordig. Moses verteenwoordig die "wette"; Elia, die "profete"; en Jesus, die wette én profete, maar selfs meer, naamlik Sy Messiasskap (Croatto 2005:465)!

In sy PhD-tesis doen Van der Walt (2014) 'n vergelykende studie oor wonders wat gedurende hierdie drie epogs plaasvind. Tydens definiëring van wat wonders is, merk Van der Walt (2014:34) dat die woorde vir tekens (אוֹ ['owth /oth/]) en wonders (מופת [mowpheth]) daarop dui dat 'n gegewe teken en of wonder vooruit of terug kan wys. Met ander woorde, na iets wat gaan kom (byvoorbeeld, oordeel) of reeds gebeur het (om geheue te verfris). Verder kom hy agter dat daar merkbare ooreenkomste is in wonders, wat gedurende hierdie epogs voorkom. Moses hou byvoorbeeld sy kierie uit oor die Riet-see en lei dan die Israeliete droogvoets deur (Eks. 14-15); Elia slaan met sy mantel op die Jordaan-rivier en stap dan droogvoets saam met Elisa deur (2 Konings 2:8); Jesus loop nie deur 'n see of rivier nie, maar loop in eie krag, sonder kierie of mantel, bo-op water.

Van der Walt $(2014: 10,11)$ se metodologie om die wonderverhale te bestudeer, behels ' $n$ eksegetiese model wat aantoon dat ooreenkomste tussen die wonderverhale in die drie verskillende epogs op vier vlakke, naamlik struktuur, plekke (settings), temas en motiewe, uitgeken kan word. ${ }^{1}$ Die hipotetiese vraag wat dan onwillekeurig na vore kom, is waarom hierdie merkbare ooreenkomste? Is die ooreenkomste bloot toevallig, of is dit so dat een verhaal op 'n ander verhaal gebou is (Brodie 1983:457; Poirier 2003:233; Waltke 2007:719; DeVries 1985:210)?² Indien dit wel die

1 Vir ' $n$ volledige beskrywing van wonderverhale in die drie genoemde epogs, sien Van der Walt (2014).

2 Daar is heelwat navorsing op die gebied van intertekstualiteit gedoen wat ook meer lig op hierdie vraag kan werp (Robbins 1994:179; Waaijman 2010:1; Brawley 1993:429; Cromhout 2009:588; Van Zyl 1994:350). Intertekstualiteit is 
geval is, naamlik dat een storie op 'n ander storie gebou is, word 'n derde vraag geopper: Hoe vêr kan so 'n storie gaan?

Hierdie artikel poog om laasgenoemde vraag versigtig te beantwoord deur die motief ${ }^{3}$ van water, wat in drie mikro-verhale in die verskillende epogs ter sprake is, met mekaar te vergelyk. ${ }^{4}$ Hoewel die hooffokus in die volgende paragrawe op die motief van water gaan wees, is dit wel moontlik dat daar oorvleueling met ander narratologiese elemente soos struktuur, plekke ("settings") en spesifieke verhaaltemas kan wees, soos wat Van der Walt (2014:10) se eksegetiese model wel aandui.

\section{WATERMOTIEF IN EKSODUS 14-15}

Een van die grootste wonderverhale in die Ou Testamentiese Kanon is opgeteken in Eksodus 14 en 15, die deurtog deur die Riet-see. Hier is sprake van baie water, so die watermotief is heel duidelik!

Van der Walt (2014:109) sluit by Patterson (2004:44) aan deur hierdie mikro-verhaal van die ander kant af (Eks. 15) te beskryf, met ander woorde, nadat die Israeliete deur die Riet-see getrek het en die Egiptiese soldate verdrink het. Die rede hiervoor is tweërlei:

\subsection{Eksodus 15 besing YHWH se heerskappy oor die hele skepping}

Eksodus 15 is nie alleen 'n pragtige, gestruktureerde gedig nie, maar staan ook bekend as een van die oudste geskrifte in die Ou Testamentiese Kanon (Butler 1971:256; Butts 2010:170; Halpern 2003:53). ${ }^{5}$ Butler (1971:258) meen dat die gedig gedurende Israel se ballingskap (586 v.C.) in sy finale vorm gegiet is. Aanvanklik het die gedig uit twee elemente bestaan, naamlik 'n feestelike seremonie, wat Israel se verkiesing as YHWH se volk besing het, en gemeenskaplike klaagliedere waarin daar oor die goeie verlede met YHWH as Koning/Leier nagedink is. Volgens Butler (1971:258),

egter 'n vakgebied op sy eie en ruimte in hierdie artikel laat nie 'n breedvoerige bespreking van hierdie onderwerp toe nie.

3 'n Motief kan beskryf word as 'n dominante, kenmerkende, of selfs bindende gedagte/voorwerp/item, wat in 'n verhaal of verhale voorkom (Van der Walt 2014:11).

4 As gevolg van beperkte ruimte word daar slegs op een wonderverhaal in elke epog, waar 'n watermotief te vinde is, gefokus.

5 Vir ' $n$ indiepte beskrywing van die geskiedenis en struktuur van hierdie gedig, sien Butler (1971:61-247). 
verteenwoordig die nuwe gedig 'n fees waarin YHWH se Koningskap besing word.

Van der Walt (2014:111) het 'n tabel saamgestel wat spesifieke beskrywende woorde in Eksodus 15 oor YHWH se oppermag uitlig. Hierdie woorde bevestig wie $\mathrm{Hy}$ is; wat $\mathrm{Hy}$ gedoen het; en wat $\mathrm{Hy}$ gaan doen.

Wie Hy is:

- יהוֹה (YHWH) - Here (Eks. 15:1 die bestaande een [Strong 3068; Hol 3193]), verhewe (Eks. 15:1,21) [הָז / ga'ah]; Strong 1342; TWOT 299; $B D B$ 144b, 1085d);

- (my) Sterkte/Krag (Eks. 15:2 [iy / 'oz]; Strong 5797; Hol 6175);

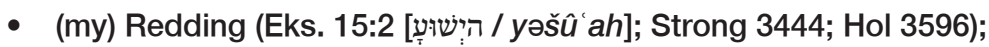

- (my) God (Eks. 15:2 [N / 'êl,]; Strong 410; Hol 436);

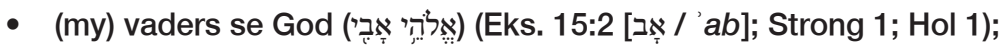

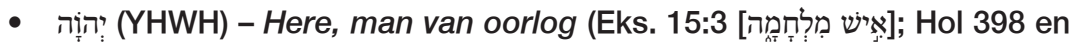
4658);

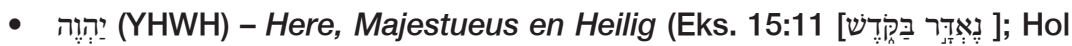
148 en 7423);

- יִּזוֹה (YHWH) - Here, wat gevrees moet word [of] gevreesde Een (Eks. 15:11 [ ] în]]; Hol 3509).

Wat Hy gedoen het:

- רָָָ \{ramah\} (Eks. 15:1,4 [gegooi, of geslinger]; Strong 7411) perd en wa in die see;

- רֵָ \{raats\} (Eks. 15:6 [verbrokkel]; Strong 07492) die vyand;

- הרז \{harac\} (Eks. 15:7 [vernietig]; Strong 2040) hulle wat Hom opponeer;

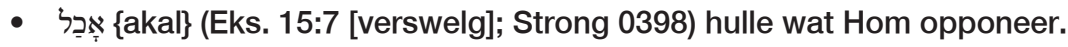

Wat Hy gaan doen:

- נָזָ \{nachah\} (Eks. 15:13 [lei]; Strong 05148) hulle vir wie Hy verlos het;

- נָּה \{nahal\} (Eks. 15:13 [stuur]; Strong 05095) hulle na Sy woonplek;

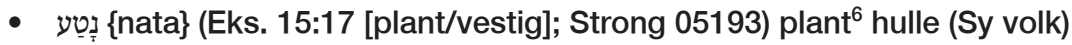
op die berg van Sy erfenis;

6 "When YHWH plants individuals, He rewards them with fertility and security" (Propp 1998:569). 


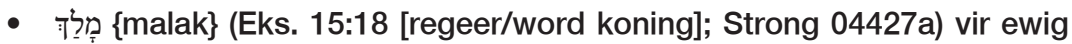
en altyd.

Bostaande skema wys duidelik dat Eksodus 15 uitsluitlik oor YHWH gaan. $\mathrm{Hy}$ is Israel se Koning en geen vyand kan teen Hom staande bly nie. Hy (YHWH) gebruik die see om te red, maar ook om 'n oordeel te vel. Farao se arrogansie word in Eksodus 15:9 beskryf, maar dit is van korte duur. Vers 10 beskryf wat Farao se grootheidswaan vir hom en sy soldate op die hals haal, hulle sink soos lood [עפרֶ]]. YHWH, Skeppergod, ontmoet Farao nie op laasgenoemde se terme, met swaard, spies en strydwa nie (Fretheim 1991:169). Met Sy regterhand (vers 6) en Sy asem [חำ] (vers 10),

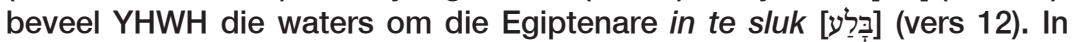
plaas daarvan dat Farao Israel weer in sy mag neem, word hy deur YHWH

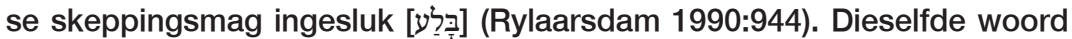

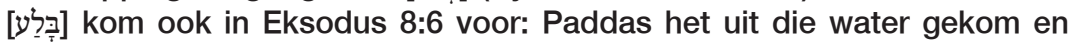
die land verswelg/bedek. ${ }^{7}$ Farao, wat YHWH se skeppingsplan met Israel wou vernietig, word nou self deur die skepping vernietig; hy sink soos lood $^{8}$ in die watermassas ${ }^{9}$ in. Die watermotief wat kunstig in Eksodus 15 uitgebeeld word, is dus 'n goeie voorbeeld van hoe 'n teken/wonder die leser se aandag heen-en-weer (vooruit en terugwysend) kan stuur.

Eksodus 15 besing ook YHWH se skeppingsmag oor die feit dat Hy die see kan beheer soos wat Hy wil (vers 8). In Eksodus 14:16 word vertel dat YHWH vir Moses opdrag gee om sy kierie te lig en sy hand oor die see uit te steek sodat die see kan oopkloof. Dit herinner aan YHWH se woorde in Eksodus 4:17 waar YHWH vir Moses sê dat hy baie tekens en wonders met die kierie gaan doen. Meyers (2005:115) noem dat die splitsing van die see die Eksodus verhaal na 'n nuwe vlak neem. Kan daar 'n groter wonder as hierdie ene plaasvind?

Die taal in Eksodus 14 is die van 'n kosmiese oorlog. Dit is 'n oorlog tussen chaos (waarvan Farao verteenwoordigend is) en orde, met YHWH wat mag oor orde en chaos het. Hy kan die skepping/natuur beheer en

$7 \quad$ Hier is 'n stuk ironie: Die Egiptiese godin, Heqet, was beskou as die godin van vrugbaarheid. Haar voorkoms was met die van 'n padda uitgedruk. Met die padda-plaag in Eksodus 8 wys $\mathrm{YHWH}$ dat Hy alleen skeppingsmag het. Farao wou verhoed dat Israel vermeerder, deur hul babatjies in die Nyl te gooi. Vanuit die Nyl kom daar dan 'n oordeel (paddas) oor Farao omdat hy teen YHWH se skeppingsplan met Israel wil werk.

$8 \quad$ Vir 'n verduideliking op die sinspeling tussen lood en klippies en hoe dit verder met oordeel verband hou, sien Van der Walt (2014:113).

9 In die antieke wêreld is geglo dat die onderwêreld (plek van die dooies) diep onder die watermassas was. 
omkeer soos wat Hy wil. Uiteindelik is dit hierdie wonder, die splitsing van die see, wat Israel beweeg om te erken dat YHWH alleen God is (Eks. 14:31).

\subsection{Eksodus 15 dien as oorgangsverhaal wat ook vooruit wys}

Eksodus 15 dien, aan die een kant, as 'n soort opsomming van die teologiese basis van die boek Eksodus in sy geheel (Durham 1987:210). Aan die ander kant, dien Eksodus 15 ook as 'n hefboom, of oorgang, tussen die Eksodus-tradisie (Eks. 1-14) en die Woestyn-tradisie (Eks. 16-18), wat die suggestie van 'n nuwe begin onder die Koningskap van YHWH versterk (Patterson 2004:44; Childs 1974:249). ${ }^{10}$ Die suggesties oor wie YHWH is, wat Hy gedoen het, maar veral ook wat Hy gaan doen, maak dat Eksodus 15 veral gedurende moeilike tye, soos byvoorbeeld die ballingskapsperiode in 586 v.C. vir Israel vertroos en bemoedig. Hierdie lied sou hulle daaraan herinner dat YHWH alleen God is, hul God; Een wat hulle gered het en ook weer sal red.

Childs (1974:249) wys daarop dat Israel geen aandeel in hul verlossing uit Egipte gehad het nie. Hulle het nie eens daartoe saamgewerk nie. Dit lyk in teendeel, behalwe vir Eksodus 15, of hulle meermale vir YHWH geopponeer het. Die watermotief in Eksodus 15 kan dus ook vooruit wys as 'n waarskuwing. Indien Israel vir YHWH sou opponeer, kan dieselfde onheil wat Egipte getref het, hulle ook tref (Eks. 15:26).

\section{WATERMOTIEF IN 2 KONINGS 2}

Poirier (2003:233) merk dat die Elia-verhaal in 1 Konings 17-2 Konings 2 dieselfde patroon as die Eksodus-verhaal volg, amper asof 'n storie op 'n storie gebaseer is. Elia se verhaal is net baie meer kompak. Soos wat die Eksodus-verhaal begin met ' $n$ koning wat nie in YHWH geglo het nie, begin Elia se verhaal eintlik reeds in 1 Konings 16:29-34, met die beskrywing van die Omri-dinastie waarin Agab en Jesebel as boos beskryf word (Brodie 2000:1), die ergste in Israel se geskiedenis (Waltke 2007:715). Dit is tydens hierdie slegte deel van Israel se geskiedenis wat YHWH vir Elia as sy profeet kies om op te tree.

Die verhale rondom Elia lyk amper uit plek uit binne die makronarratief van 1 en 2 Konings. Dit kom voor asof die makro-narratief skielik onderbreek word. Dit is presies wat Elia se opwagting is, 'n onderbreking. Elia verskyn vanuit die niet en onderbreek en versteur die verhaal, deurdat

10 'n Belangrike betekenis van water as motief is die feit dat dit op 'n nuwe begin, of nuwe lewe dui (Van der Walt 2014:108). 
hy die koningshuis se godsdienstige motiewe bevraagteken en uitdaag (Birch et al. 1999:266; Brueggemann 2001:34). Hierdie onderbreking is daar met ' $n$ rede, want dit is wat YHWH doen. Hy onderbreek en versteur die "normale orde". Hy het dit ook in die Eksodus-verhaal gedoen. Soos wat YHWH vir Moses gebruik het, het Hy ook via Elia wonders gedoen, waarvan die aanskoulikste die gebeure op Karmel was toe Elia die Baalpriesters met vuur uitgedaag het (1 Kon. 18). Met wondertekens word Israel (veral die eerste leser wat in Ballingskap verkeer) herinner dat YHWH en nie Baal nie, alleen God is (Van der Walt 2014:189-190).

Daar is heelwat parallelle tussen wonders wat Elia gedoen het en wat Moses gedoen het. ${ }^{11}$ Vir die doel van hierdie artikel word daar slegs op die watermotief in 2 Konings 2 gefokus.

\subsection{Konings 2 bevestig YHWH se skeppingsmag via Sy profete Elia en Elisa}

2 Konings 2 beskryf Elia se laaste reis op aarde (Patterson \& Austel 1988:174). Elia was op weg na Gilgal (2 Kon. 2:1) en Elisa, wat hy as sy opvolger gesalf het (1 Kon.19:19), vergesel hom. Gedurende Elia se reis stel hy by drie geleenthede voor dat Elisa moet agter bly. Eerstens toe hulle van Gilgal na Bethal op pad was, toe weer tydens hul tog vanaf Bethal na Jerigo, en derdens toe hulle van Jerigo in die rigting van die Jordaan gereis het $(2$ Kon. 2:2, 4, 6). Elisa hou telkens vol dat hy met hierdie reis end-uit saam met Elia sal bly. Die roete wat hulle volg, is dieselfde roete wat Israel gevolg het toe hulle die beloofde land onder die leierskap van Josua betree het (Condon 2006:3).

By die Jordaan het Elia sy mantel geneem en op die water geslaan: Dit het na weerskante toe opgekloof sodat hulle droogvoets kon deurloop (2 Kon. 2:8). Gedurende Elia se reis lyk dit op die oog af of Elia huiwerig was om sy profeetskap aan Elisa te oorhandig, of dat hy Elisa dalk wou toets om te sien of hy wel bereid is om sy nuwe rol as profeet ernstig op te neem (Condon 2006:4; Patterson \& Austel 1988:175; Olley 1998:46). In 1 Konings 19:19 het Elia sy mantel oor Elisa gegooi ('n teken dat hy hom as sy opvolger aanwys), maar in 2 Konings 2:13 gooi hy sy mantel op die grond, sodat Elisa dit self moes optel nadat Elia weggeneem is. Die eerste leser word egter subtiel deur hierdie vreemde gebeure daaraan herinner dat die verhaal nie oor Elia of Elisa in die eerste plek handel nie, maar dat YHWH die eintlike hoofkarakter is (Van der Walt 2014:187).

11 Sien Van der Walt (2014:375-377) se vergelykende tabelle in dié verband. 
Die feit dat hulle dieselfde roete as Israel gevolg het, wys terug na YHWH wat vir Israel die beloofde land in gelei het. Elia wat sy mantel op die grond neergooi, dui waarskynlik daarop dat hy nie self oor mag beskik nie, maar dat alle mag aan YHWH behoort. Hierdie suggestie word versterk deur Elisa se optrede die oomblik toe hy die mantel self optel en vir YHWH aanroep (2 Kon. 2:14-15). Terwyl hy YHWH aanroep, het hy op die Jordaan geslaan en het die water weer oopgegaan sodat hy kon deurloop. Dit herinner aan YHWH wat vir Moses opdrag gegee het om sy kierie oor die Riet-see te hou sodat dit kan oopgaan (Rice 2006/2007:5). Die mantel beskik nie oor een of ander magiese krag nie. Die handeling en Elisa wat na die Here roep, dui daarop dat YHWH alleen oor skeppingsmag beskik en in beheer is (Bronner 1968:127; Olley 1998:46).

\subsection{Konings 2 dien as oorgangsverhaal en kondig ' $n$ nuwe tyd aan}

Wanneer Elia in 2 Konings 2:8 op die water slaan en dit oopkloof, herinner dit die leser aan Eksodus 14 toe Moses sy kierie oor die Riet-see gehou het sodat dit kon oopgaan (Condon 2006:7; Rice 2006/2007:5). Dit bring ook in herinnering van die Jordaan wat oopgegaan het toe Israel uiteindelik die beloofde land sou begin beset het (Burnett 2010:286-287; Condon 2006:7; Keil \& Delitzsch 2011:207). Voorts suggereer die oopgaan van die Jordaanrivier dat 'n nuwe wending in die verhaal gaan aanbreek. Dit is wel die geval, want Elia word in die hemel opgeneem en Elisa bly agter. Elisa tel dan Elia se mantel op, wat daarop dui dat hy sy roeping as YHWH se profeet aanvaar (Condon 2006:7). Hy beweeg terug op die roete waarvandaan hulle gekom het, weer deur die Jordaan wat oopgaan, wat weereens daarop dui dat nog 'n nuwe era aanbreek. YHWH is nie klaar nie; Hy het nie vergeet nie; $\mathrm{Hy}$ is steeds teenwoordig en op weg met Sy volk. Die verhaal het dus 'n oop einde (Van der Walt 2014:193).

\section{WATERMOTIEF IN MATTEUS 14:22-33}

Water as motief is nie vreemd aan die Sinoptiese evangelies nie. In die evangelie van Markus, byvoorbeeld, word daar nie minder as 49 keer direk na die see verwys of word dit in die verhaal ingebring nie (Ellenburg 1995:174). Water dien ook 'n belangrike omgewing of ruimte te wees waarby Jesus werksaam is: Jesus roep Sy eerste dissipels by die see (Mark 1:16, 19, 20); Jesus doen lering en maak mense gesond by die see (Mark 2:13; 3:7; 4:1).

Water as motief dui ook op die feit dat tradisionele grense op tweërlei vlak oorgesteek word. In die eerste plek, vind lering gewoonlik in 'n tempel 
plaas, maar Jesus doen Sy lering meestal by die see. Tweedens, dui die watermotief op tradisionele grense wat oorgesteek word. Jesus gaan oor (die water) na die ander kant, na die heidene toe en werk nie soos 'n Joodse rabbi net onder die Jode nie (Malbon 1984:364). Om hierby aan te sluit, merk Malbon (1984:369-372) verder die gebruik van rigtingaanwysings (Oos-na-Wes en Wes-na-Oos). Die doel met hierdie rigtingaanwysings was waarskynlik om die feit te beklemtoon dat Jesus Sy dissipels aanmoedig om ook buite hul "tradisionele godsdienstige" grense te gaan werk en na nuwe terreine oor te beweeg.

Twee verhale wat in dié verband in die evangelies uitstaan, is Jesus wat op die water loop (Matt. 14:22-33; Mk. 6:45-52; Joh. 6:15-21) en Jesus wat die storm op die see stilmaak (Matt. 8:23-27; Mark 4:35-41; Luk. 8:22-25). Vir die doel van hierdie artikel word daar op die eerste genoemde verhaal, volgens die evangelie van Matteus, ${ }^{12}$ gefokus.

\subsection{Matteus 14:22-33 bevestig Jesus se Messiasskap en mag oor die skepping}

Jesus demonstreer Sy mag oor die skepping wanneer Hy 'n storm stilmaak (Matt. 8:23-27) en wanneer Hy op die see loop (Matt. 14:22-33). Dit is belangrik om daarop te let dat geen hindernis (watermassa) vir Jesus onoorkombaar is nie. Ook stuit geen bose magte Hom nie (Newman \& Stine 1988:2; Twelftree 1999:103, 114; Van der Walt 2014:282). Wanneer Jesus die storm stil maak, is Sy dissipels verwonderd en vra die vraag: "Watter soort mens is Hy dat selfs die wind en die see na Hom luister?" (Matt. 8:27). Dit is heel waarskynlik die manier waarop Jesus die storm aanspreek en die feit dat die wind nie alleen gaan lê nie, maar die water is ook onmiddellik stil, wat die inhoud van die dissipels se vraag verskerp. Jesus bestraf (غ่ $\pi \varepsilon \tau i \mu \eta \sigma \varepsilon \nu$ (Matt. 8:26 BGT) letterlik die see, asof Hy 'n bose mag aanspreek (Twelftree 1999:113; Hendriksen 1974:412). ${ }^{13}$ Die antwoord op die dissipels se vraag word vir die eerste keer deur twee persone wat met bose geeste gevul is, geantwoord: Jesus is die Seun van God (Matt. 8:29). Later sou Jesus self op hierdie vraag antwoord: "Dit is Ek"

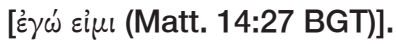

12 Die evangelie volgens Matteus gee 'n goeie aanduiding oor hoe 'n bepaalde wonderwerk na gebeure in die verlede, maar ook die toekoms kan wys (Van der Walt 2014:303).

13 In die antieke wêreld is daar geglo dat die bodem van die see en nog dieper die aarde in vol boosheid was. Die sogenaamde onderwêreld. Dit verklaar die dissipels se vrees wanneer hulle uitroep dat hulle gaan vergaan, aan die een kant (Matt. 8:25), maar ook die feit dat hulle Jesus vir 'n spook aansien, aan die ander kant (Matt. 14:26). 
In die aanloop tot Jesus se antwoord, "dit is Ek", bevind Sy dissipels hulself sonder Jesus in 'n skuit op die see. In opdrag van Jesus was hulle besig om na die oorkant toe te vaar. Hulle word weer deur die golwe geteister ( $\beta a \sigma a v i \zeta o ́ \mu \varepsilon v o v$ (Matt. 14:24 BGT) en die wind is van voor (teen hulle)..$^{14}$ Die suggestie is daar dat hulle nou, in die afwesigheid van Jesus, getoets word. Die vraag was reeds in Matteus 8:26 gevra: "Waarom is julle bang, kleingelowiges?". Wanneer Jesus in Matteus 14 op die see na hulle toe aangeloop kom, is die veronderstelling daar dat Hy weet dat hulle bang is en antwoord dan bevestigend op die vraag in Matteus 8,

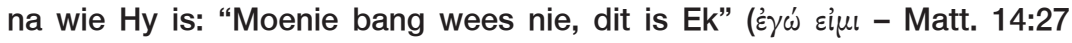
BGT)! Hierdie woorde herinner aan die narratief in Eksodus 3-4 toe YHWH eweneens vir Moses aangespreek het: "Moenie bang wees nie, dit is Ek" (Crusemann 2002:101; Hill 1982:248).

Jesus se opdrag dat hulle nie bang moet wees nie herinner ook aan YHWH se woorde aan die Israeliete wat teen die Riet-see vasgekeer was terwyl die Egiptenare hulle agtervolg het (Eks. 14:15). Voorts het YHWH die Israeliete beveel om verder te trek, ten spyte van die watermassa wat voor hulle was. In Matteus 14:29 beveel Jesus op Petrus se aandrang dat Petrus na Hom toe moet kom, ten spyte van die watermassa tussen hulle. ${ }^{15}$

Wanneer Jesus uiteindelik saam met hulle in die boot klim en die wind weereens bedaar (sien Matt. 8), bely die dissipels dit wat die twee besetenes in Matteus 8 reeds gesê het: Jesus is waarlik die Seun van God. Hy is verhewe bo die skepping; Hy kan dit beheer soos wat Hy wil (Lockyer 1961:201).

\subsection{Matteus 14:22-33 dien as 'n oorgangsverhaal}

Wanneer daar na die Matteus-evangelie in sy geheel gekyk word (makronarratief), is dit duidelik dat die evangelie in 'n duidelik simmetriese struktuur tussen narratief en diskoers altereer. Lohr (1961:427) stel dit skematies as volg voor:

14 Die woord vir teister in hierdie konteks verwys waarskynlik na iemand wat gemartel word om inligting uit die persoon te verkry; dit kan ook verwys na 'n soort polleerklippie wat gebruik was om die suiwerheid van goud te toets (Strong 2001:928; Hendriksen 1989:599).

15 Petrus se kleingeloof oorweldig hom en hy sink. Dit blyk dat hy nie die "toets", naamlik om op Jesus te vertrou, deurstaan het nie (Nielsen 1975:48) 


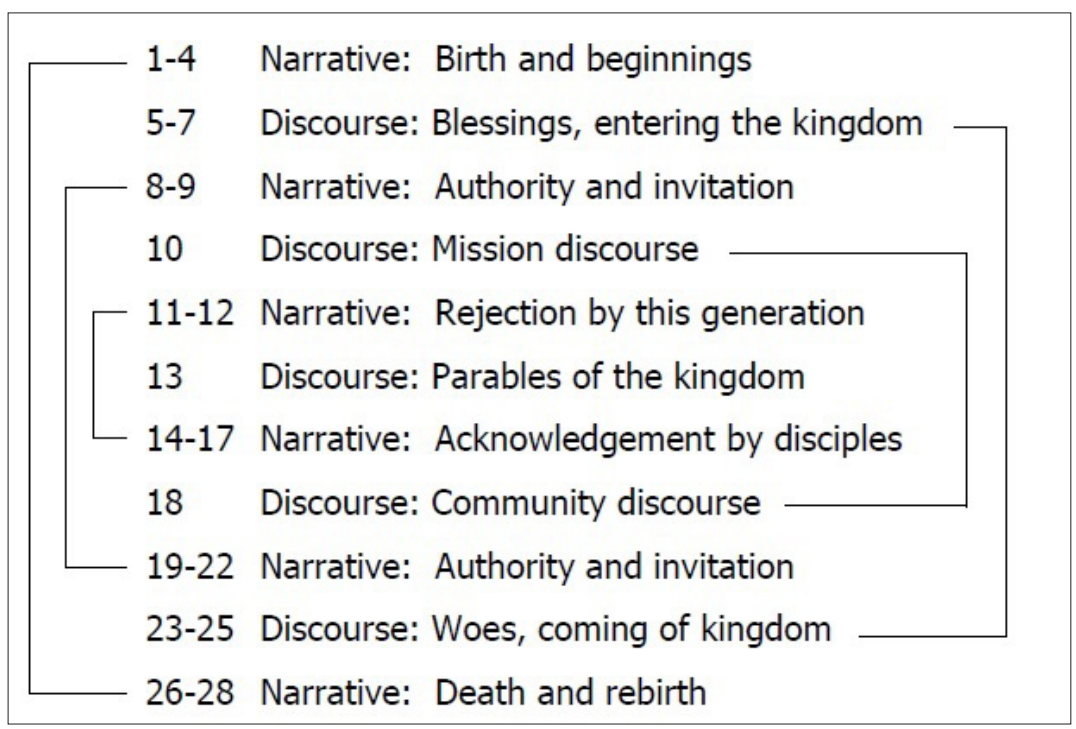

Lohr (1961:428) verduidelik dan verder dat die struktuur vir die leser 'n sleutel gee oor hoe die evangelie volgens Matteus in geheel verstaan behoort te word. Die senter van die evangelie bestaan uit gelykenisse oor die Koningryk. Rondom hierdie gelykenisse is daar ' $n$ wisselwerking tussen narratief en diskoers. Met ander woorde, mikro-verhale staan nie op hul eie nie, maar is met ander verhale verbind, sodat daar 'n vorentoe-agtertoe wisselwerking plaasvind. Verhale kan na gebeure vorentoe wys, maar kan ook terug wys en herinnering stimuleer.

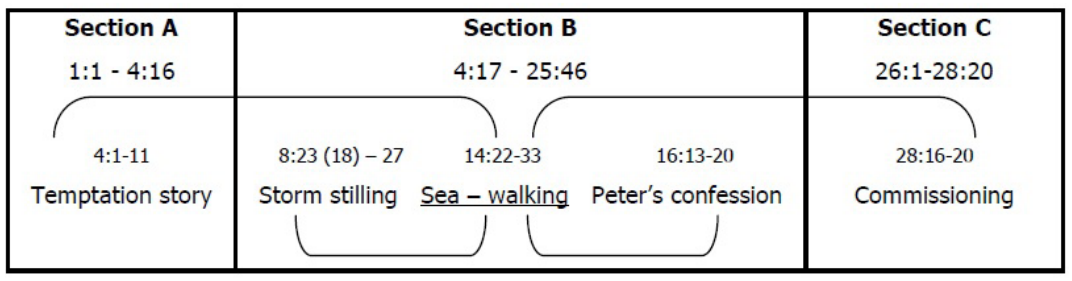

Scott $(2000: 96,97)$ wys egter daarop dat daar mikro-narratiewe in Matteus se evangelie is wat op tematiese vlak ook met mekaar verbind kan word en dat hulle interafhanklik van mekaar is, soos wat die volgende skema voorstel: 
Scott se model wys dat die narratief van Jesus wat op die see loop, baie naby aan die middel van die evangelie van Matteus geplaas is. Matteus 14:22-33 word dus as 'n hefboom, of oorgangsverhaal binne die makro-narratief gesien (Scott 2000:93) en verbind dus mikronarratiewe wat voor-en-na die see-loop-verhaal staan (Matt. 8:23-27; Matt. 16:13-20) met mekaar. Bogenoemde diagram van Scott wys dus wat in die wonderverhale gebeur; hulle wys terug en ook vorentoe. Verder wys Scott se diagram dat Matteus 14:22-33 'n konneksie met Matteus 4:1-11 (versoeking in die woestyn) en Matteus 28:16-20 (Jesus se laaste opdrag aan die dissipels) het.

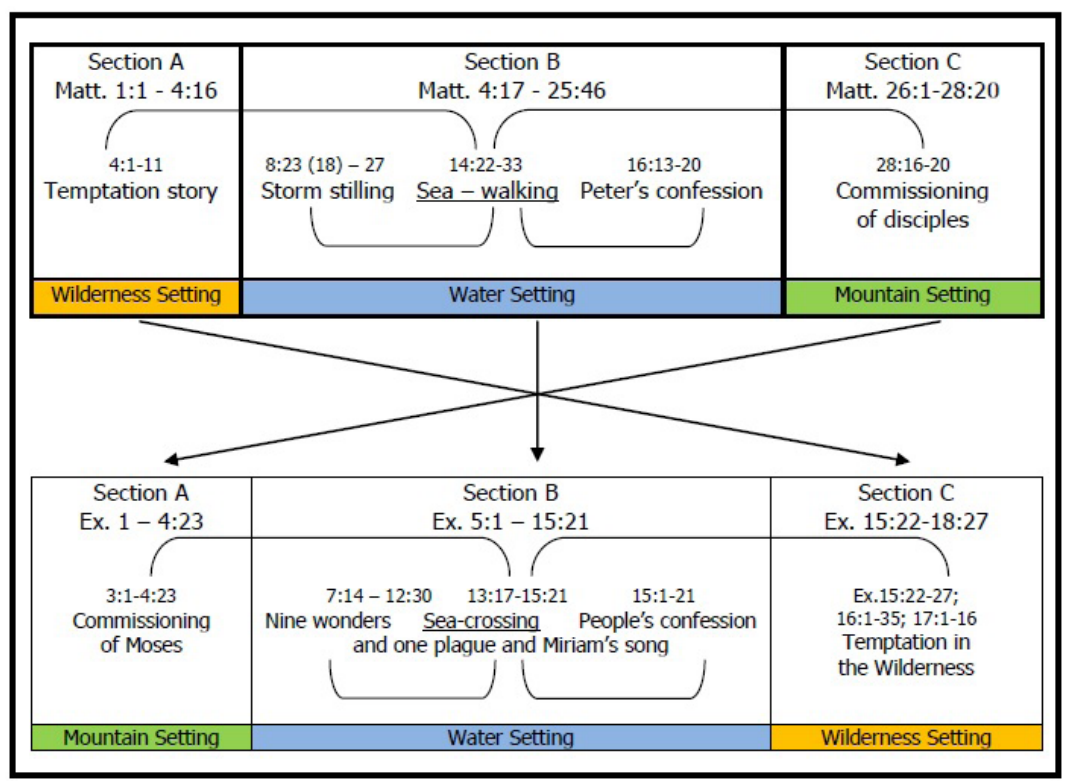

Van der Walt (2014:307) let op dat daar in die drie seksies (A B C) van Scott se model drie plekke ("settings") van belang is: Seksie A vind plaas in 'n woestyn; Seksie B is oorwegend op see; Seksie C is op 'n berg. Van der Walt (2014:307) gebruik dan Scott se model om Matteus se evangelie met Eksodus 1-18 te vergelyk. Van der Walt brei Scott se model uit deur die drie plekke van belang in te voeg. Die ooreenkomste tussen Matteus 1-28 en Eksodus 1-18 wat deur hierdie model (Van der Walt 2014:307) uitgebeeld word, is merkwaardig. Let op dat dit egter in omgekeerde orde is: 
Die uitkoms van die uitgebreide model is om aan te toon dat Matteus se evangelie, net soos Eksodus 1-18, 'n "hefboom" (water-motief) het. In albei vergeleke makro-narratiewe word 'n nuwe wending dus deur die "hefboom" (watermotief) aangedui. Gebrek aan bladruimte maak dit nie moontlik om Scott se uitgebreide model en vergelyking met Eksodus in hierdie artikel te bespreek nie. Wat wel van belang vir die doel van hierdie artikel is, is om die ooreenkomste met betrekking tot die watermotief as "hefboom" raak te sien. Dieselfde geld vir 2 Konings 2 (Elia en Elisa wat deur die Jordaan stap). In al drie verhale wat in die drie verskillende epogs plaasvind, suggereer die watermotief 'n nuwe wending of verloop in die verhaal.

Die omgekeerde orde in bogenoemde model skep die indruk dat Jesus begin waar Israel geëindig het, in die woestyn (Van der Walt 2014:361). Jesus slaag die toets in die woestyn, wat Israel nie kon regkry nie. Die see-loop-narratief in Matteus 14 wys dat die dissipels ook nie die toets ( $\left.\beta a \sigma a v i \zeta \zeta^{\prime} \mu \varepsilon \nu \circ v\right)$ geslaag het nie. In Matteus 14:31 gryp Jesus Petrus se hand. Hy los nie vir Petrus om te sink as Petrus die "toets" nie slaag nie.

Matteus 14 wys egter ook vooruit na die laaste opdrag, waar Jesus 'n nuwe bedeling in die Koninkryk aan Sy dissipels toevertrou (Matt. 28:16-20). In Matteus 28:16-20 gee Jesus aan Sy dissipels die opdrag om na al die nasies toe te gaan om hulle (die nasies) te leer wat hulle by Jesus geleer het, met die versekering dat Jesus altyd saam met hulle sal wees (Matt. 28:20). Net soos Elia, vaar Jesus op, en net soos met Elia se verhaal in 2 Konings 2, eindig Matteus se evangelie met 'n oop einde.

\section{BEVINDINGE}

'n Vlugtige verkenningstog wat op die motief van water in drie mikroverhale in drie verskillende epogs plaasvind, wys dat daar onmiskenbare ooreenkomste in hierdie verhale is. Om mee te begin, kan die wonders wat hier plaasvind, nie misgekyk word nie. In al drie verhale blyk dit dat 'n sekere watermassa vir God geen hindernis is nie: Moses lig sy kierie in die rigting van die Riet-see en die see word oopgekloof; Elia en Elisa slaan met ' $n$ mantel op die Jordaan-rivier en die rivier gaan oop; Jesus kloof nie 'n see of rivier oop nie, Hy loop bo-op water.

'n Vergelykende studie van bogenoemde drie wonderverhale toon aan dat daar in die motief van water raakpunte is. 


\subsection{YHWH se skeppingsmag word benadruk}

Binne die raamwerk van Eksodus 1-18 as makro-verhaal, toon YHWH via sy agent, Moses, deur middel van wondertekens dat $\mathrm{Hy}$ mag oor die skepping het. As Skeppergod kan Hy Sy skepping beheer en omkeer soos wat Hy wil. Eksodus 15 besing en benadruk hierdie gewaarwording en beklemtoon veral die feit dat $\mathrm{YHWH}$ in beheer van die ganse skepping is.

Die watermotief in Eksodus suggereer verder dat YHWH ook beheer oor die sogenaamde onderwêreld het. Farao, as verteenwoordiger van die onderwêreld, word veroordeel en verslaan. Die water wat hom en sy soldate verswelg en hulle soos lood na die bodem sink, wys dit uit. Vir die eerste leser wat hom-/haarself in ballingskap bevind (586 v.C), herinner Eksodus 15 dusdoende dat YHWH in beheer is omdat Hy Skeppergod is. Hy kan enige omstandigheid omkeer en ook die bose (vyande) oorwin.

Die verhaal in 2 Konings 2 is ook op die ballinge in 586 v.C. gemik. Elia se verhaal, binne die konteks van die makro-narratief van 1 en 2 Konings, onderbreek die natuurlike gang van die makro-narratief. Hierdie onderbreking wys egter vir die eerste leser daarop dat YHWH enige omstandigheid, ter enige tyd kan onderbreek en verander. Die oopmaak van die Jordaan-rivier dien as herinnering dat YHWH steeds Skeppergod is en steeds in beheer is. Soos wat Hy vir Israel uit Egipte gered het, kan Hy ook vir hulle wat in ballingskap verkeer, red.

In Matteus 14 word Jesus se mag oor die skepping herbevestig. Die verhaal wys terug na Matteus 8 waar Jesus 'n storm op die see stilgemaak het. Die vraag na wie Hy dan is, wat sulke dinge kan doen, word deur Jesus self in Matteus 14:27 geantwoord: Dit is Ek! Dit sinspeel op Eksodus 3-4 toe YHWH vir Moses gesê het: "Moenie bang wees nie, dit is Ek". Jesus legitimeer Homself dusdoende in goddelike taal as die Seun van God en Sy bonatuurlike krag om op water te loop, bevestig dit. Die feit dat Jesus 'n storm stil maak en selfs op water kan loop, bevestig verder Sy mag oor die sogenaamde onderwêreld (bose).

\subsection{Die verhale dien as oorgang (hefboom)}

Eksodus 15 dien as oorgang, of te wel 'n hefboom wat twee tradisies (Eksodus en Woestyn) met mekaar verbind. Dit wys terug na wat YHWH gedoen het, maar bevestig en bemoedig ook dat Hy enduit saam met Israel sal bly. Eksodus 15, as oorgangsverhaal, wys ook vooruit na 'n nuwe begin. Dit kom egter nie sonder waarskuwing nie: Bly getrou aan YHWH en Hy sal Sy beloftes gestand doen. Draai van Hom af weg en dieselfde rampe wat Egipte getref het, kan Israel ook tref. 
In 2 Konings 2 dui die watermotief, net soos Eksodus 15, dat 'n nuwe wending in die verhaal gaan plaasvind. Elia word in die hemel opgeneem en Elisa neem by hom as profeet oor. Elisa keer egter terug op Elia se voetspore, weer deur die Jordaan. Die nuwe wending wys na 'n nuwe profeet wat die leisels by Elia oorneem. Vir die eerste leser is daar die troos: YHWH is nie klaar met Israel nie.

'n Skematiese voorstelling het mooi uitgewys hoe die watermotief in Matteus 14:22-33 as 'n soort hefboom dien wat gebeure alvorens en gebeure daarna met mekaar in verband bring. Struktureel en tematies toon Matteus se evangelie sterk ooreenkomste met Eksodus 1-18, weliswaar in 'n omgekeerde orde. Jesus begin waar Israel eindig, in die woestyn. Anders as Israel slaag Jesus beproewing; net soos Israel, slaag Petrus nie wanneer hy getoets word nie. Petrus se hand word egter deur Jesus vasgehou sodat Petrus nie sink nie en die watermotief wys vooruit na Jesus se afskeid met die spesifieke woorde: "Onthou Ek is by julle.". Die eerste lesers (wat ook die verhale van Moses en Elia geken het) van Matteus word dusdoende bemoedig, net soos die ballinge in 586 v.C. bemoedig is. God is teenwoordig. Hulle is nie alleen nie.

\subsection{Die verhale eindig oop}

Ten laaste wys die watermotief in al drie genoemde verhale in drie verskillende epogs vooruit na ' $n$ oop einde. Die oop einde is gekoppel aan 'n nuwe wending of 'n nuwe begin. In die woestyn moet Israel leer om op YHWH, Skeppergod, te vertrou. In 2 Konings 2:14 vra Elisa, terwyl hy met sy mantel die water van die Jordaan-rivier slaan: "Waar is die Here, die God van Elia?". Die water gaan dan oop, met die suggestie dat YHWH nie klaar is met Israel nie. Die verhaal lê nog oop. Matteus eindig sy verhaal ook oop, met die woorde: "Ek is by julle al die dae tot die voleinding van die wêreld".

\section{SLOT}

Hierdie artikel het met 'n paar merkers, wat deur middle van die watermotief in drie afsonderlike verhale in drie verskillende epogs uitgewys is, probeer aantoon dat dit inderdaad lyk asof een verhaal op 'n ander verhaal gebou is. Indien dit dan wel die geval sou wees, is die hipotetiese vraag wat in die inleiding gevra is, 'n legitieme vraag: Hoe vêr kan die storie dan gaan? Dit wil voorkom of die oop einde in Matteus se evangelie tog wel 'n antwoord op hierdie vraag bied: "Onthou ... !".

Die ooreenkomste wat in elke verhaal uitgewys is, maak herinnerings los. Dit help lesers om te onthou, die eerste lesers, sowel as elke generasie 
lesers daarna. Hoe ver kan die storie gaan? Tot in lengte van dae, want die einde is oop.

\section{BIBLIOGRAFIE}

Birch, B.C., Brueggemann, W., Fretheim, T.E. \& Petersen, D.L. 1999. A theological introduction to the Old Testament. Nashville, TN: Abingdon Press.

BraWLey, R.L. 1993. An absent complement and intertextuality in John 19:28-29. Journal of Biblical Literature 112(3):427-443. https://doi.org/10.2307/3267743

BRODIE, T.L. 1983. Luke 7:36-50 as an internalization of 2 Kings 4:1-37: A study in Luke's use of rhetorical imitation. Biblica 64(4):457-485.

2000. The crucial bridge: The Elijah-Elisha narrative as an interpretive synthesis of Genesis-Kings and a literary model for the Gospels. Collegeville, MN: Liturgical Press.

BRONNER, L.

1968. The stories of Elijah and Elisha. As polemics against Baal worship. Leiden: Brill. Oriental Series 1.

Brueggemann, W. 2001. Testimony to the otherwise: The witness of Elijah and Elisha. St. Louis, MO: Chalice Press.

BURNETT, J.S.

2010. Going down to Bethel: Elijah and Elisha in the theological geography of the Deuteronomistic history. Journal of Biblical Literature 129(2):281-297.

BUTLER, T.C.

1971. The song of the sea. Exodus 15:1-18: A study in the exegesis of Hebrew poetry. Unpublished Ph.D. thesis. Ann Arbor, Ml: University Microfilms.

ButTs, A.M.

2010. A note on ne' dārî in Exodus 15:6. Vetus Testamentum 60:167-171.

CHILDS, B.S.

1974. The Book of Exodus. A critical, theological commentary. Philadelphia, PA: Westminster Press.

Condon, D. 2006. The mantle passes from Elijah to Elisha. 2 Kings 2:1-15. Unpublished Ph.D. thesis. Buies Creek, NC: University Divinity School. 
Croatto, J.S.

2005. Jesus, prophet like Elijah, and prophet-teacher like Moses in Luke - Acts. Journal of Biblical Literature 124(3):451-465.

Свомноuт, $\mathrm{M}$.

2009. Identity formation in the New Testament. HTS Theological Studies 65(1):586-597.

Crüsemann, $F$.

2002. Scripture and resurrection. In: T. Peters, R.J. Russel \& M. Welker (eds), Resurrection: Theological and scientific assessments (Cambridge: W.B. Eerdmans), pp. ??.

DeVRIES, S.J.

1985. Word biblical commentary. Volume 1. 1 Kings. Waco, TX: Word Books Publisher.

Durham, J.

1987. Exodus. World biblical commentary. Volume 3. Waco, TX: Word Books Publisher.

ELLenBuRg, B.D. 1995. A review of selected narrative-critical conventions in Mark's use of miracle material. Journal of the Evangelical Theological Society 38(2):171-180.

Fretheim, T.E.

1991. Exodus. Louisville, KY: Westminster John Knox Press.

HALPERN, B.

2003. Eyewitness testimony. Parts of Exodus written within living memory of the event. Biblical Archaeology Review 29(5):50-57.

HendRIKsen, W.

1974. The Gospel of Matthew. New Testament commentary. London: Billing \& Sons Limited.

1989. Matthew. New Testament commentary. Oxford: University Printing House.

HILL, D.

1982. The New Century bible commentary. The Gospel of Matthew. Grand Rapids, MI: W.B. Eerdmans.

KeIL, C.F. \& DeLITZSCH, F. 2011. Commentary on the Old Testament. Volume 3. 1 and 2 Kings. Peabody, MA: Hendrickson Publishers.

LOCKYER, $\mathrm{H}$.

1961. All the miracles of the Bible. Grand Rapids, I: Zondervan.

LOHR, C.H.

1961. Oral techniques in the Gospel of Matthew. Catholic Biblical Quarterly 23:403-435. 
MALBON, E.S.

1984. The Jesus of Mark and the Sea of Galilee. Journal of Biblical Literature 103(3):363-377. https://doi.org/10.2307/3260778

MeYers, C. 2005. Exodus. The New Cambridge Bible commentary. Cambridge, MA: Cambridge University Press.

Newman, B.M. \& Stine, P.C.

1988. A handbook on the Gospel of Matthew. New York: UBS Handbook Series.

NieLsen, J.T.

1975. Het Evangelie naar Mattheus II. Nijkerk: Uitgeverij G.F. Callenbach.

OLLEY, J.W.

1998. YHWH and His zealous prophet. The presentation of Elijah in 1 and 2 Kings. Journal of the Study of the Old Testament 80:25-51. https://doi. org/10.1177/030908929802308002

PatTerson, R.D.

2004. Victory at sea. Prose and poetry in Exodus 14-15. Bibliotheca Sacra 161:42-54.

Patterson, R.D. \& Austel, H.J.

1988. 1, 2 Kings. The expositor's bible commentary. Volume 4, Grand Rapids, MI: Zondervan.

POIRIER, J.C.

2003. The end time returns of Elijah and Moses at Qumran. Dead Sea Discoveries 10(2):221-242. https://doi.org/10.1163/156851703322235395

Propp, W.H.C.

1998. Exodus 1-18. A new translation with introduction and commentary. The Anchor Bible. Volume 2. New York: Doubleday.

RICE, G.

2006/2007. Elijah's requirement for prophetic leadership. 2 Kings 2:1-18. The Journal of Religious Thought 59/60(1/2):1-12.

RobBins, V.K.

1994. Socio-rhetorical criticism: Mary, Elizabeth and the Magnificat as a test case. In: E.S. Malbon \& E.V. McKnight (eds), The new literary criticism and the New Testament (Sheffield: JSOT Press). Journal for the Study of the New Testament 109:164-209.

RYLAARSDAM, J.C.

1990. Introduction to the Book of Exodus. The interpreter's bible. Volume 1. Genesis and Exodus. New York: Abingdon Press.

SABOURIN, L.

1971. Old Testament miracles. Biblical Theology Bulletin 10:227-261. 
ScotT, J.M.C.

2000. Jesus walking on the sea. The significance of Matthew 14:22-23 for narrative development of the Gospel. Narrativity in biblical and related texts. Leuven: Leuven University Press.

SNYMAN, S.D.

2000. Die eksegese van die Ou Testament. Terugblik en vooruitskouing. Acta Theologica 2000(1):76-93.

StRong, J.

2001. The new Strong's expanded dictionary of bible words. Nashville, TN: Thomas Nelson Publishers.

TweLFTREe, G.H.

1999. Jesus the miracle worker. A historical and theological study. Downers Grove, ILL: Intervarsity Press.

VAN DER WALT, J.S.

2014. A biblical-theological investigation of the phenomenon of wonders surrounding Moses, Elijah and Jesus. Unpublished Ph.D. thesis. Bloemfontein: University of the Free State.

VAN ZYL, H.C.

1994. Die Nuwe Afrikaanse Vertaling. Verwysingsbybel. Hermeneutiese besinning. Nederduits Gereformeerde Teologiese Tydskrif 35:345-358.

WAAIJMAN, K. 2010. Intertextuality. On the use of the Bible in mystical texts. HTS Theological Studies 66(1):1-7. https://doi.org/10.4102/hts.v66i1.895

WALTKE, B.C.

2007. An Old Testament theology. Grand rapids, MI: Zondervan.

Keywords

Moses

Elija

Jesus

Water motif
Trefwoorde

Moses

Elia

Jesus

Watermotief 